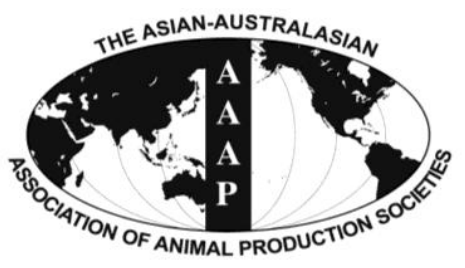

Asian-Aust. J. Anim. Sci.

Vol. 25, No. $10: 1451-1456$

October 2012

www.ajas.info

http://dx.doi.org/10.5713/ajas.2012.12253

\title{
Effect of Bacteriophage Supplementation on the Growth Performance, Nutrient Digestibility, Blood Characteristics, and Fecal Microbial Shedding in Growing Pigs
}

\author{
L. Yan, S. M. Hong and I. H. Kim* \\ Department of Animal Resource and Science, Dankook University, Cheonan, Choognam 330-714, Korea
}

\begin{abstract}
BSTRACT: A total of 144 ((Duroc $\times$ Yorkshire $) \times$ Landrace)) pigs with an average initial BW of $28.85 \pm 0.63 \mathrm{~kg}$ were used in this 6-wk growth trial. Pigs were randomly allotted to 1 of 4 treatments in a completely random block design. Each dietary treatment consisted of 9 replicate pens, with 4 pigs per replicate. Dietary treatments included: i) NC (basal diet), ii) PC (NC+apramycin $0.5 \mathrm{~g} / \mathrm{kg}$ ), iii) BPT1 (NC+bacteriophage $0.25 \mathrm{~g} / \mathrm{kg}$ ) and iv) BPT2 (NC+bacteriophage $0.5 \mathrm{~g} / \mathrm{kg}$ ). The inclusion of antibiotics and bacteriophages did not affect the ( $>>0.05)$ ADG, ADFI and G:F compared with the basal diet. Dietary antibiotics and bacteriophages supplementation led to a higher $(\mathrm{p}<0.05) \mathrm{DM}$ digestibility than the NC treatment. Pigs fed the bacteriophage supplemented diet increased $(\mathrm{p}<0.05)$ the $\mathrm{N}$ digestibility compared with those fed NC treatment. Supplementation of antibiotics led to a higher $(\mathrm{p}<0.05)$ energy digestibility than the NC treatment. No difference ( $p>0.05$ ) was observed in the RBC, WBC, lymphocyte concentration and fecal moisture among treatments. Pigs fed PC and BPT2 treatments reduced $(\mathrm{p}<0.05)$ the $E$. coli concentration compared with those fed NC treatment. The inclusion of BPT2 treatment led to a higher $(\mathrm{p}<0.05)$ lactobacillus concentration compared with $\mathrm{NC}$ and PC treatment. Dietary antibiotic and bacteriophage supplementation reduced $(\mathrm{p}<0.05)$ the Salmonella concentration compared with NC treatment. In conclusion, our study suggested that bacteriophage at the level of $0.5 \mathrm{~g} / \mathrm{kg}$ could be used as an antibiotics alternative for growing pigs. (Key Words: Bacteriophages, Growth, Digestibility, Fecal Microbes, Growing Pigs)
\end{abstract}

\section{INTRODUCTION}

With the ban of antibiotic utilization in livestock for growth promotion, bacterial infection of the animal became emerging problem in pig industry. Thus, there was increased interest of finding better antibiotic alternatives against bacterial infection and subsequently promoting the growth performance in pigs (Yan et al., 2010; Yan et al., 2011a;b; Yan et al., 2012). Among these alternative, bacteriophages had received great attention in the discussion about developing suitable alternative for antibiotics growth promoter in livestock industry (Jamalludeen et al., 2009; Lee and Harris, 2001)

As demonstrated elsewhere, bacteriophages are nonharzardous self-replicating agent that can infect and multiply in bacteria to prevent bacterial diseases. Smith and Huggins (1982) have previously suggested that the treatment of $E$. coli infected mice with phages was more effective than treatment with antibiotics. Lee and Harris

\footnotetext{
* Corresponding Author: I. H. Kim. Tel: +82-41-550-3652, Fax: +82-41-565-2949, E-mail: inhokim@dankook.ac.kr Submitted May 10, 2012; Accepted Jul. 3, 2012; Revised Jul. 11, 2012
}

(2001) demonstrated that administration of a single broadspectrum anti-Salmonella phage to Salmonella challenged young pigs could reduce Salmonella concentration in several tissues. Jamalludeen et al. (2009) also suggested that the inclusion of phages could prevent the E. coli induced diarrhea in weaned pigs. However, most of those previous studies were conducted under bacterial challenge condition, only a limited research had been conducted under normal physiological state. Recently, our previous study reported that the inclusion of bacteriophgaes could also benefit the laying hens in egg production and egg quality under normal physiological state (Zhao et al., 2012).

Thus, the aim of the present study was to evaluate the effects of bacteriophages on growth performance, nutrient digestibility, blood characteristics, fecal microbial shedding and fecal moisture in growing pigs, we hypothesized the inclusion of bacteriophages could also benefit the animal performance under normal state.

\section{MATERIALS AND METHODS}

The experimental protocols were approved by the 
Animal Care and Use Committee of Dankook University.

\section{Experimental design, animals, and housing}

Bacteriophages used in our study contain Salmonella gallinarum, Salmonella typhimurium, and S. Enteritidis. The concentration of bacteriophages is $10^{8}$ plaque forming unit per gram. A total of 144 ((Duroc $\times$ Yorkshire) $\times$ Landrace)) pigs with an average initial BW of $28.85 \pm 0.63$ $\mathrm{kg}$ were used in this 6-wk growth trial. Pigs were randomly allotted to 1 of 4 treatments in a completely random block design. The bacteriophage was administrated by replacing the same amount of corn. Each dietary treatment consisted of 9 replicate cages, with 4 pigs per replicate (two barrows and two gilts). Dietary treatments included: i) NC (basal diet), ii) PC (NC+apramycin $0.5 \mathrm{~g} / \mathrm{kg}$ ), iii) $\mathrm{BPT} 1 \quad \mathrm{NC}+$ bacteriophage $0.25 \mathrm{~g} / \mathrm{kg}$ ) and iv) BPT2 (NC+bacteriophage

Table 1. Feed composition of control diet (as-fed basis)

\begin{tabular}{|c|c|}
\hline Item & Diet \\
\hline \multicolumn{2}{|l|}{ Ingredient (\%) } \\
\hline Corn & 49.30 \\
\hline wheat & 10.00 \\
\hline Rice bran & 1.42 \\
\hline Wheat bran & 2.00 \\
\hline Soybean meal & 23.72 \\
\hline $\begin{array}{l}\text { DDGS } \\
\text { (dried distiller's grain with solubles) }\end{array}$ & 5.00 \\
\hline Limestone & 0.22 \\
\hline Animal fat & 2.50 \\
\hline Molasses & 3.00 \\
\hline Salt & 0.30 \\
\hline Choline (50\%) & 0.07 \\
\hline Methionine (99\%) & 0.04 \\
\hline L-lysine & 0.26 \\
\hline DCP (Dicalcium phosphate) & 1.46 \\
\hline Threonine (100\%) & 0.02 \\
\hline Mineral premin $x^{1}$ & 0.55 \\
\hline Vitamin premix ${ }^{2}$ & 0.14 \\
\hline Total & 100.00 \\
\hline \multicolumn{2}{|l|}{ Calculated composition (\%) } \\
\hline Crude protein & 18.0 \\
\hline Crude fat & 5.39 \\
\hline Crude ash & 5.26 \\
\hline L-lysine & 0.97 \\
\hline Calcium & 0.70 \\
\hline Phosphorus & 0.65 \\
\hline \multicolumn{2}{|c|}{ 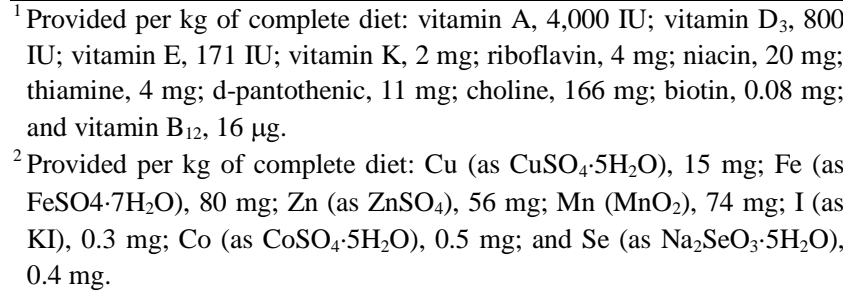 } \\
\hline
\end{tabular}

$0.5 \mathrm{~g} / \mathrm{kg}$ ). Diets (Table 1) were formulated to meet or exceed the nutrient requirements recommended by NRC (1998). Pigs were housed in an environmentally controlled, slatted-floor facility in 36 adjacent pens $(1.8 \times 1.8 \mathrm{~m})$ at the pig farm of Dankook University. All pigs were provided with ad libitum access to feed and water through a selffeeder and nipple drinker, respectively, throughout the experiment. The target room temperature and humidity were $25^{\circ} \mathrm{C}$ and $60 \%$, respectively.

\section{Sampling and measurements}

Pig weights were measured at the beginning and the end of the experiment period, feed consumption were recorded on a pen basis during the experiment to calculate ADG, ADFI, and G:F. Chromium oxide was added to the diet as an indigestible marker at $0.20 \%$ of the diet for $7 \mathrm{~d}$ prior to fecal collection at the 6th wk for calculation of DM, N, and energy digestibility. Fecal grab samples were collected at random from at least 2 pigs in each pen (1 gilt and 1 barrow) at the end of the study. All feed and feces samples were stored immediately at $-20^{\circ} \mathrm{C}$ until analysis. All the feed and fecal samples were freeze-dried and finely ground to be able to pass through a 1-mm screen. The determination of $\mathrm{DM}, \mathrm{N}$, and energy digestibility were conducted in accordance with the methods established by the AOAC (2000). Chromium levels were determined via UV absorption spectrophotometry (UV-1201, Shimadzu, Kyoto, Japan). The gross energy was determined by measuring the heat of combustion in the samples using a Parr 6100 oxygen bomb calorimeter (Parr instrument Co., Moline, IL, USA). The CATTD of DM, N, and energy were calculated using indirect methods described by Williams et al. (1962).

Two pigs were randomly selected from each pen (1 gilt and 1 barrow) and bled via jugular venipuncture at the beginning of the experiment $(0 \mathrm{~d})$. The same pigs were bled at the end $(35 \mathrm{~d})$ of the experiment. Blood samples were collected into vacuum tubes containing $\mathrm{K}_{3}$ EDTA (Becton Dickinson Vacutainer Systems, Franklin Lakes, NJ, USA) to obtain whole blood. The red blood cells (RBC), white blood cells (WBC) and lymphocyte counts of whole blood samples were determined using an automatic blood analyzer (ADVIA 120, Bayer, Tarrytown, NY, USA).

At the end of experiment, fecal samples were collected via massaging the rectum from 2 pigs randomly selected from each pen ( 1 gilt and 1 barrow) and pooled and placed on ice for transportation to the laboratory, where analysis was immediately carried out. The composite fecal sample (1 g) from each pen was diluted with $9 \mathrm{ml}$ of $10 \mathrm{~g} / \mathrm{L}$ peptone broth (Becton, Dickinson and Co., Rutherford, NJ, USA) and homogenized. Viable counts of bacteria in the fecal samples were then conducted by plating serial 10-fold 
Table 2. Effects of bacterphage on growth performance in growing pigs ${ }^{1}$

\begin{tabular}{lccccc}
\hline Items & NC & PC & BPT1 & BPT2 & SE $^{2}$ \\
\hline ADG $(\mathrm{g})$ & 459 & 464 & 455 & 472 & 20 \\
ADFI (g) & 1,284 & 1,231 & 1,294 & 1,272 & 46 \\
G/F & 0.357 & 0.377 & 0.352 & 0.371 & 0.009
\end{tabular}

${ }^{1} \mathrm{NC}=$ Basal diet (negative control); PC = Basal diet +22 ppm tylosin (positive control); $\mathrm{BPT} 1=\mathrm{NC}+0.025 \%$ bacterphage; $\mathrm{BPT} 2=$ $\mathrm{NC}+0.05 \%$ bacterphage.

${ }^{2}$ Standard error.

dilutions (in $10 \mathrm{~g} / \mathrm{L}$ peptone solution) onto MacConkey agar plates (Difco Laboratories, Detroit, MI, USA) and lactobacilli medium III agar plates (Medium 638, DSMZ, Braunschweig, Germany) to isolate the E. coli and Lactobacillus, respectively. The lactobacilli medium III agar plates were then incubated for $48 \mathrm{~h}$ at $39^{\circ} \mathrm{C}$ under anaerobic conditions. The MacConkey agar plates were incubated for $24 \mathrm{~h}$ at $37^{\circ} \mathrm{C}$. The E. coli and Lactobacillus colonies were counted immediately after removal from the incubator. For Salmonella, the serially diluted peptone broth tubes were incubated overnight at $37^{\circ} \mathrm{C}$, after which $1 \mathrm{ml}$ was transferred to $9 \mathrm{ml}$ of tetratinate broth (Neogen Corporation, Lansing, MI, USA) and then incubated for 48 $\mathrm{h}$ at $42^{\circ} \mathrm{C}$. From these tubes, $1 \mathrm{ml}$ was used to inoculate 9 $\mathrm{ml}$ of Rappaport Vassiliadis broth (Neogen Corporation) and incubated for $48 \mathrm{~h}$ at $42^{\circ} \mathrm{C}$. The Rappaport was used to inoculate XLT4 plates for Salmonella isolation, and the Salmonella was then identified using LIS and TSI agar tubes (Difco Laboratories). Moreover, pigs excreta samples were collected and placed in aluminum foil cups. The aluminum foil cups were weighed and placed in a drying oven at $100^{\circ} \mathrm{C}$ for $24 \mathrm{~h}$ and then reweighed to calculate moisture loss. The incidence of diarrhea in piglets was observed and recorded 3 times (8:00, 14:00 and 20:00) per day during the study.

To assess the severity of diarrhea, fresh faeces from all pigs were scored during d 5 to 10 (most serious period) by determining the moisture content according to the method of Hart and Dobb (1988). Briefly, scores were 0, normal, firm faeces; 1, possible slight diarrhea; 2, definitely unformed, moderately fluid faeces; or 3 , very watery and frothy diarrhea. The occurrence of diarrhea was defined as maintaining faecal scores of 2 and 3 for 2 consecutive days.

\section{Statistical analyses}

Data were analyzed by ANOVA using the General Linear Models (GLM) procedure of SAS (SAS Institute, 1996), with the pen being defined as the experimental unit. Differences among treatments were separated by Duncan's multiple range test. The results were expressed as the least squares means and SE. Probability values less than 0.05
Table 3. The effects of bacterphage on nutrient digestibility in growing pigs ${ }^{1}$

\begin{tabular}{lccccc}
\hline Items (\%) & $\mathrm{NC}$ & $\mathrm{PC}$ & $\mathrm{BPT} 1$ & $\mathrm{BPT} 2$ & $\mathrm{SE}^{2}$ \\
\hline Dry matter & $77.40^{\mathrm{b}}$ & $80.08^{\mathrm{a}}$ & $79.34^{\mathrm{a}}$ & $79.57^{\mathrm{a}}$ & 0.56 \\
Nitrogen & $77.00^{\mathrm{b}}$ & $78.43^{\mathrm{ab}}$ & $80.13^{\mathrm{a}}$ & $79.22^{\mathrm{a}}$ & 0.59 \\
Energy & $76.63^{\mathrm{b}}$ & $79.22^{\mathrm{a}}$ & $77.79^{\mathrm{ab}}$ & $78.46^{\mathrm{ab}}$ & 0.67 \\
\hline
\end{tabular}

${ }^{1} \mathrm{NC}=$ Basal diet (negative control); $\mathrm{PC}=$ Basal diet $+22 \mathrm{ppm}$ tylosin (positive control); $\mathrm{BPT} 1=\mathrm{NC}+0.025 \%$ bacterphage; $\mathrm{BPT} 2=$ $\mathrm{NC}+0.05 \%$ bacterphage.

${ }^{2}$ Standard error.

${ }^{a, b}$ Means in the same row with different superscripts differ $(\mathrm{p}<0.05)$.

were considered significant.

\section{RESUTLS}

\section{Growth performance}

The inclusion of antibiotics and bacteriophages did not affect the $(\mathrm{p}>0.05)$ ADG, ADFI and G:F ratio compared with the basal diet (Table 2).

\section{Nutrient digestibility}

Dietary antibiotics and bacteriophages supplementation led to a higher $(\mathrm{p}<0.05) \mathrm{DM}$ digestibility than the NC treatment (Table 3). Pig fed the bacteriophages supplemented diet increased $(\mathrm{p}<0.05)$ the $\mathrm{N}$ digestibility compared with those fed NC treatment. Supplementation of antibiotics led to a higher $(p<0.05)$ energy digestibility than the NC treatment. No difference $(p>0.05)$ was observed among antibiotic treatment and bacteriophages supplemental diet.

\section{Blood characteristics}

No difference ( $p>0.05$ ) was observed on the RBC, WBC, and lymphocyte concentration among treatments (Table 4).

\section{Fecal microbial shedding and fecal moisture}

Pig fed PC and BPT2 treatment reduced $(\mathrm{p}<0.05)$ the $E$. coli concentration compared with those fed NC treatment (Table 5). The inclusion of BPT2 treatment led to a higher $(\mathrm{p}<0.05)$ lactobacillus concentration compared with $\mathrm{NC}$ and PC treatment. Dietary antibiotic and bacteriophages supplementation significantly reduced $(p<0.05)$ the salmonella concentration compared with $\mathrm{NC}$ treatment. No difference $(p>0.05)$ was observed on the fecal moisture throughout the experiment.

\section{DISCUSSION}

In the current study, the inclusion of antibiotics did not affect the growth performance of pigs throughout the experiment, although it increased the dry matter digestibility and energy digestibility at the end of this study. 
Table 4. Effects of bacterphage on fecal microflora and diarrhea score in growing pigs ${ }^{1}$

\begin{tabular}{|c|c|c|c|c|c|}
\hline Items & $\mathrm{NC}$ & PC & BPT1 & BPT2 & $\mathrm{SE}^{2}$ \\
\hline \multicolumn{6}{|c|}{ Red Blood cell $\left(10^{6} / \mu \mathrm{l}\right)$} \\
\hline $0 \mathrm{wk}$ & 6.23 & 6.20 & 6.53 & 6.64 & 0.17 \\
\hline $6 \mathrm{wk}$ & 7.07 & 6.37 & 5.95 & 6.33 & 0.36 \\
\hline \multicolumn{6}{|c|}{ White blood cell $\left(10^{3} / \mu \mathrm{l}\right)$} \\
\hline $0 \mathrm{wk}$ & 22.11 & 21.00 & 25.02 & 21.37 & 2.41 \\
\hline $6 \mathrm{wk}$ & 21.75 & 20.65 & 20.70 & 19.40 & 1.95 \\
\hline \multicolumn{6}{|c|}{ Lymphocyte (\%) } \\
\hline $0 \mathrm{wk}$ & 54.65 & 48.45 & 61.20 & 55.68 & 4.95 \\
\hline $6 \mathrm{wk}$ & 60.68 & 54.10 & 59.88 & 63.91 & 4.76 \\
\hline
\end{tabular}

In agreement with this study, our previous studies (Wang et al., 2009; Yan et al., 2011b) also suggested pig fed the antibiotics supplemented diet did not affect the growth performance but led to a higher nutrient digestibility in growing pigs. As we known, the effect of antibiotic growth promoter (AGP) on the growth performance could be affected by many factors such as environment, animal age, and administration dosage. Therefore, we hypothesized that the reason for the lack effect of antibiotic could be attributed to the good sanitation condition of the experiment facility. It is well suggested that antibiotic supplementation could decrease the pathogenic bacterial in the intestine, and subsequently increased the nutrient digestibility of pigs. Our results suggested that the inclusion of antibiotics reduced the E. coli and Salmonella concentration compared with basal diet. Nagy and Fekete (1999) had previously suggested that $E$. coli are shed by clinically healthy animals, and may cause a drop in nutrient digestibility and growth performance in livestock. Forshell and Wierup (2006) also suggested that Salmonella is a pathogen of considerable importance in worldwide animal production. Therefore, the reason for the increase nutrient digestibility is likely to be the improved intestine gut health caused by antibiotics supplementation.

Similarly, administration of bacteriophge did not affect the growth performance compared with those without bacteriophage supplementation, which is partially in agreement with Gebru et al. (2010), who suggested that supplementation of bateriophgae did not affect the growth performance and feed intake in growing pigs under normal state. But interestingly, the inclusion of bacteriophage increased the nutrient digestibility compared with the basal diet, which was comparable to those with antibiotics supplementation. Barrow (2001) had previously reported that bacteriophages have therapeutic value as antiSalmonella agent in pigs. Wall et al. (2010) also suggested that administration of anti-Salmonella phage to pigs challenged with Salmonella could reduce Salmonella colonization by 90 to $99.9 \%$ in the ileum and cecum. It is well known that gastrointestinal microflora play a number of important roles in animal production because intestine is the largest nutrient adsorption part in the pigs; therefore, a possible reason for the increased digestibility is likely to be the increased gut health of the pigs due to the bacteriopages supplementation. This hypothesis is strength by our results on the fecal microbial shedding, wherein the inclusion of bacteriophage decreased the E. coli and Salmonella concentration. Moreover, a higher lactobacillus concentration was also observed with the bacteriophages supplementation at the level of $0.5 \mathrm{~g} / \mathrm{kg}$. Metchnikoff (1908) had previously suggested that lactobacillus could balance the intestinal environment, prevent the growth of pathogenic bacteria and subsequently benefit the animal production. Therefore, the increased lactobacillus

Table 5. Effects of bacterphage on fecal microflora and diarrhea score in growing pigs ${ }^{1}$

\begin{tabular}{lccccc}
\hline Items & NC & PC & BPT1 & BPT2 & SE $^{2}$ \\
\hline E. coli $(\log 10 \mathrm{cfu} / \mathrm{g})$ & $6.55^{\mathrm{a}}$ & $6.00^{\mathrm{b}}$ & $6.32^{\mathrm{ab}}$ & $6.14^{\mathrm{b}}$ & 0.10 \\
Lactobacillus $(\log 10 \mathrm{cfu} / \mathrm{g})$ & $6.89^{\mathrm{b}}$ & $6.93^{\mathrm{b}}$ & $7.16^{\mathrm{ab}}$ & $7.52^{\mathrm{a}}$ & 0.14 \\
Salmonella $(\log 10 \mathrm{cfu} / \mathrm{g})$ & $3.62^{\mathrm{a}}$ & $2.57^{\mathrm{b}}$ & $2.21^{\mathrm{b}}$ & $2.02^{\mathrm{b}}$ & 0.51 \\
Diarrhea score $^{3}$ & 0.05 & 0.04 & 0.05 & 0.04 & 0.01 \\
Fecal moisture & 62.43 & 62.47 & 63.12 & 62.91 & 1.14 \\
\hline
\end{tabular}

${ }^{1} \mathrm{NC}=$ Basal diet (negative control); $\mathrm{PC}=$ Basal diet+22 ppm tylosin (positive control); $\mathrm{BPT} 1=\mathrm{NC}+0.025 \%$ bacterphage; $\mathrm{BPT} 2=\mathrm{NC}+0.05 \%$ bacterphage. ${ }^{2}$ Standard error. ${ }^{3}$ Fecal score: 0 , normal; 1 , soft feces; 2 , mild diarrhea; 3 , severe diarrhea.

${ }^{\mathrm{a}, \mathrm{b}}$ Means in the same row with different superscripts differ $(\mathrm{p}<0.05)$. 
concentration may also reflect the improved nutrient digestibility in the current study. The reason for improved lactobacillus is likely to be the reduced E. coli and Salmonella concentration, which provided a better ecosystem for the development of the lactobacillus.

It is well accepted that gastrointestinal is the largest immunologically competent organ in the body, the maturation and optimal development of the immune system depend on the development and composition of the indigenous microflora and vice versa (de Vrese and Marteau, 2007). Our results also indicated that the inclusion of antibiotics and bacteriophages benefited the microflora in the intestine. Therefore, we hypothesized that the blood characteristics could be affected by the inclusion of antibiotics or bacteriophages, because the blood characteristic is always considered as a sensitive response to various treatment. Unluckily, results of current study were out of anticipation and no difference was observed, which is inconsistent with our previous study (Yan et al., 2011c), who suggested that the inclusion of antibiotics could increase the lymphocyte concentration in growing pigs. It should be noted that the antibiotics used in this two studies were used in two different dosages, therefore, the reason for the difference may be the different dosages used in this study. Besides, to the best of our knowledge, there is no research investigating the effect of bacteriophages supplementation on the blood characteristics under normal states. Therefore, no comparison could be made with the current study. Collectively, we cannot make any statements regarding the effects of bacteriophages on the blood characteristics in the current study.

\section{CONCLUSION}

In conclusion, our study suggested that the bacteriophages at the level of $0.5 \mathrm{~g} / \mathrm{kg}$ could be used as an antibiotics alternative for growing pigs.

\section{ACKNOWLEDGEMENT}

This work was supported by a grant from the BioGreen 21 Program (No. PJ008121), Rural Development Adminstration, Republic of Korea.

\section{REFERENCES}

AOAC. 2000. Official methods of analysis. 17th ed. Association of Official Analytical Chemists. Gaithersburg, MD.

Barrow, P. 2001. The use of bacteriophages for treatment and prevention of bacterial disease in animals and animal models of human infection. J. Chem. Technol. Biotechnol. 76:677-682.

de Vrese, M. and P. R. Marteau. 2007. Probiotics and prebiotics: Effects on diarrhea. J. Nutr. 137:803S-811S.
Forshell, L. P., and M. Wierup. 2006. Salmonella contamination: A significant challenge to the global marketing of animal food products. Rev. Sci. Tech. Off. Int. Epizoot. 25:541-554.

Gebru, E., J. S. Lee, J. C. Son, S. Y. Yang, S. A. Shin, B. Kim, M. K. Kim and S. C. Park. 2010. Effect of probiotics, bacteriophage, or organic acid supplemented feeds or fermented soybean meal on the growth performance, acute phase response, and bacterial shedding of grower pig challenged with Salmonella enteric serotype Typhimurium. J. Anim. Sci. 88:3880-3886.

Hart, G. K. and G. J. Dobb. 1988. Effect of a fecal bulking agent on diarrhea during enteral feeding in the critically ill. J. Parenter. Enteral Nutr. 12:465-468.

Jamalludeen, N., R. P. Johnson, P. E. Shewen and C. L. Gyles. 2009. Evaluation of bacteriphages for prevention and treatment of diarrhea due to experimental enterotoxigenic Escherichia coli O149 infection of pigs. Vet. Microbiol. 136:135-141.

Lee, N. and D. L. Harris. 2001. The Effect of Bacteriophage Treatment as a Preharvest Intervention Strategy to Reduce the Rapid Dissemination of Salmonella typhimurium in Pigs. American Association of Swine Veterinarians (AASV), Perry, IA: AASV, pp. 555-557.

Metchnikoff, E. 1908. The prolongation of life: optimistic studies. London: Heinemann. pp. 116-132.

Nagy, B. and P. Z. Fekete. 1999 Enterotoxigenic Escherichia coli (ETEC) in farm animal. Vet. Res. 30:259-284

National Research Council. 1998. Nutrient requirement of pigs 10th Ed. National Academy Press, Washington, DC, USA.

SAS. 1996. SAS user's guide: Statistics. Version 7.0th edn. SAS Institute, Cary, North Carolina.

Smith, H. W. and M. B. Huggins. 1982. Successful treatment of experimental Escherichia coli infections in mice using phage: its general superiority over antibiotics. J. Gen. Microbiol. 128: 307-318

Wang, J. P., J. S. Yoo, H. J. Kim, J. H. Lee and I. H. Kim. 2009. Nutrient digestibility, blood profiles and fecal microbiota are influenced by chitooligosaccharide supplementation of growing pigs. Livest. Sci. 125:298-303.

Wall, S. K., J. Zhang, M. H. Rostagno and P. D. Ebner. 2010. Phage therapy to reduce pre-processing Salmonella infections in market weight swine. Appl. Environ. Microbiol. 76:48-53. doi:10.1128/AEM.00785-09.

Williams, C. H., D. J. David and O. Iismaa. 1962. The determination of chromic oxide in faeces samples by atomic absorption spectrophotometery. J. Agric. Sci. 59:381-385.

Yan, L., J. P. Wang, H. J. Kim, Q. W. Meng, X. Ao, S. M. Hong and I. H. Kim. 2010. Influence of essential oil supplementation and diets with different nutrient densities on growth performance, nutrient digestibility, blood characteristics, meat quality and fecal noxious gas content in grower-finisher pigs. Livest. Sci. 128:115-122.

Yan, L., Q. W. Meng and I. H. Kim. 2011a. The effects of dietary Houttuynia cordata and Taraxacum officinale extract powder on growth performance, nutrient digestibility, blood characteristics and meat quality in finishing pigs. Livest. Sci. 141:188-193

Yan, L., J. H. Lee, Q. W. Meng and I. H. Kim. 2011b. Evaluation of the Anion supplementation on growth performance, nutrient 
digestibility, blood characteristics and fecal noxious gas content in weaning pigs. J. Appl. Anim. Res. 39:36-40.

Yan, L., Q. W. Meng and I. H. Kim. 2011c. The effect of an herb extract mixture on growth performance, nutrient digestibility, blood characteristics and fecal noxious gas content in growing pigs. Livest. Sci. 141:143-147
Yan, L., Q. W. Meng and I. H. Kim. 2012. Effect of an herb extract mixture on growth performance, nutrient digestibility, blood characteristic, and fecal microbial shedding in weaning pigs. Livest. Sci. 145:189-195.

Zhao, P. Y. and I. H. Kim. 2012. Effects of bacteriophage supplementation on egg performance, egg quality, excreta microflora, and moisture content in laying hens. Asian-Aust. J. Anim. Sci. 25:1015-1020. 